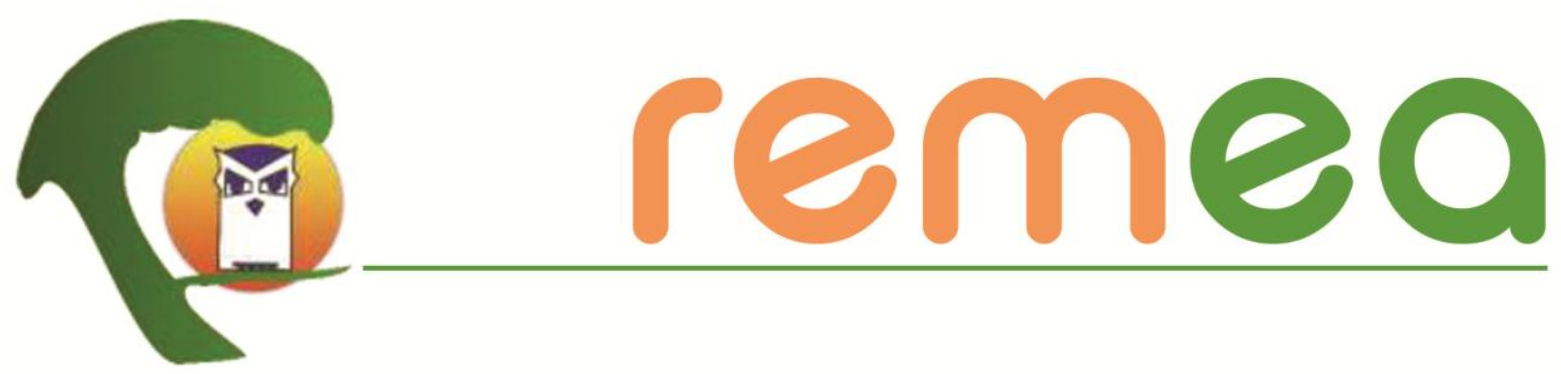

\title{
Apresentação Dossiê ANPED GT 22
}

\author{
Paula Corrêa Henning ${ }^{1}$ \\ Universidade Federal do Rio Grande - FURG \\ ORCID: http://orcid.org/0000-0003-3697-9030 \\ Shaula Maíra Vicentini de Sampaio ${ }^{2}$ \\ Universidade Federal Fluminense - UFF \\ ORCID: https://orcid.org/0000-0002-8898-3659 \\ Luiz Marcelo de Carvalho ${ }^{3}$ \\ Universidade Estadual Paulista - UNESP \\ ORCID: https://orcid.org/0000-0002-6109-6830
}

Era meados dos anos 2000 e a Educação Ambiental fortalecia-se com mais um espaço de encontros e reflexões acerca de seu campo de saber. Consolidava-se, junto à Associação Nacional de Pós-Graduação e Pesquisa em Educação, o Grupo de Trabalho em Educação Ambiental no ano de 2005: o GT22. Ali, muitas composições teóricas e metodológicas se produziram, muitos colegas se articularam para pensar juntos a EA no Brasil. A partir desse

\footnotetext{
${ }^{1}$ Doutora em Educação, professora do Programa de Pós-Graduação em Educação em Ciências e do Programa de Pós-Graduação em Educação Ambiental da Universidade Federal do Rio Grande - FURG. Líder do Grupo de Estudos em Educação, Cultura, Ambiente e Filosofia - GEECAF/FURG. Bolsista Produtividade do CNPq 2. Coordenadora do GT 22 Educação Ambiental da ANPED (2019-2021). Rio Grande, Brasil. E-mail: paula.c.henning@gmail.com

${ }^{2}$ Licenciada e Bacharel em Ciências Biológicas pela Universidade Estadual de Campinas (UNICAMP), com mestrado e doutorado em Educação pela Universidade Federal do Rio Grande do Sul (UFRGS). Professora do Departamento de Biologia Geral e do Programa de Pós-Graduação em Educação da Universidade Federal Fluminense (UFF). Vice-coordenadora do GT 22 Educação Ambiental da ANPED (2019-2021). E-mail: shaula.maira@gmail.com

${ }^{3}$ Licenciado em Ciências Biológicas pela Faculdade de Filosofia, Ciências e Letras/Barão de Mauá, com mestrado em Ecologia e Recursos Naturais pela Universidade Federal de São Carlos e doutorado em Educação pela Universidade de São Paulo. Credenciado junto ao Programa de Pós-Graduação em Educação da UNESP Instituto de Biociências/Campus de Rio Claro-SP e Programa de Pós-Graduação em Educação para a Ciência, Unfei / Itajubá - MG. Membro do Comitê Científico do GT 22 Educação Ambiental da ANPED.

E-mail:Im.carvalho@unesp.br
} 
momento, conquistou-se um relevante espaço institucional para discussões produtivas e acaloradas acerca da Educação Ambiental, para a realização de apresentações de pesquisas, assim como para a proposição de questionamentos epistemológicos e políticos que, paulatinamente têm fortalecido o campo. É desse espaço que o presente Dossiê nos fala. Nessa edição de dezembro/2021 são enfocados os Movimentos Teóricos e Metodológicos produzidos no/com o Grupo de Trabalho 22 Educação Ambiental da ANPED. O intuito é, portanto, trazer para a cena diferentes artigos decorrentes de investigações consolidadas no interior de grupos de pesquisa brasileiros, que dão vida às reuniões bianuais dessa importante associação nacional.

O objetivo desse Dossiê é oferecer à comunidade científica produções que evidenciem os movimentos epistemológicos e metodológicos que vêm constituindo um dos principais espaços de fortalecimento e luta política no campo da Educação Ambiental no nosso país. Na sala do GT 22 se produziam ações que, numa visão moderna de ciência, poderíamos dizer que demonstravam consolidações epistemológicas. Entretanto, não é dessa visão que partimos ao nos referirmos aos encontros do GT 22 e aos estudos que nesse Dossiê demarcam as produções que daí se desdobram. Não se trata da assepsia científica. Muito pelo contrário! O que falamos aqui tem mais eco com as resistências e ações políticas que se fortalecem, ano após ano, nos encontros coletivos dos grupos de pesquisa que potencializam as atividades do GT.

Importantes pesquisadores da EA criaram um coletivo dedicado a pensar e provocar movimentos frente às questões ambientais no cenário nacional. Desde lá, muitos outros foram agregando-se a essa composição de professores/as e estudantes de pós-graduação do Brasil.

É dessa luta política, de defesa à Educação Ambiental que os textos desse Dossiê nos falam. É de um movimento que vem compondo forças há quase duas décadas que reunimos 19 artigos no intuito de demarcar posição, firmar passagem nesses tempos de ataques e retrocessos às políticas públicas em Educação Ambiental em nosso país. A leitura dos artigos que compõem esse número da REMEA poderá evidenciar o esforço dos organizadores em reforçar e demarcar os espaços significativos criados por diferentes grupos de pesquisa em Educação Ambiental, espalhados pelo país, em provocar esses movimentos de 
"consolidação, conservação e subversão" (BORDIEU, 1983) nos processos de produção de conhecimento no campo da Educação Ambiental. Esforços anteriores nessa mesma direção podem ser constatados em publicações coletivas do GT: uma delas publicada em 2009, em um dos números de Educação e Ambiente (VOL. 14, número 2) e outra, em 2010, em um número da Pesquisa em Educação Ambiental (volume 5, número 2).

Nesse sentido, a escrita desse Dossiê é um modo de, uma vez mais, a EA encontrar possibilidades de respiro para anunciar sua importância e demarcar as relações entre ciência, ética e política. Tramadas entre si, elas podem oferecer a nós, pesquisadores/as, um modo potente de discutir sobre as análises que produzimos no encontro com nossos objetos discursivos e problematizar os atravessamentos políticos que daí se derivam. Fazemos política ao assumir posição e defender a Educação Ambiental em diferentes espaços sociais e educacionais. Miramos a EA de outros modos que não aqueles determinados por supostas respostas imediatas aos problemas ambientais que vivemos, ou ainda pelo crivo do desenvolvimento sustentável. Fazemos política ao resistir ao estabelecido em legislações que esvaziam a EA, justo porque nossas pesquisas são encharcadas de ética e estudos que demarcam a importância desse campo de saber para a vida de humanos e não-humanos no planeta.

A escrita desse dossiê se faz com textos de ciência, ética e política, tramados e misturados, porque a ciência não é pura e neutra. É dessa ciência que tratamos aqui. Essa edição da REMEA é uma maneira de cavar espaço para anunciar nossas investigações e resistir ao nosso presente (FOUCAULT, 1995; DELEUZE, 1988). Esse presente que nos assola, nos adormece, nos enfraquece. Encontrando forças junto a esse coletivo definimos posição e anunciamos que o/a intelectual da Educação Ambiental faz política com suas pesquisas e anuncia suas posições em diferentes frentes, lugares e escritas. Esse Dossiê é apenas um dos espaços políticos e epistemológicos a partir do qual o campo da Educação Ambiental vem mostrando sua força contra os ataques que se fazem cotidianamente às múltiplas formas de existir no mundo.

Por fim, agradecemos a esse coletivo e convidamos o leitor a pensar conosco nos modos possíveis de resistir e conviver em tempos de retrocessos da Educação, da Ciência e da Ética em nosso país. Boa leitura a todos nós! 


\section{Referências}

BOURDIEU, P. O campo científico. In: ORTIZ, R. (Org.). Pierre Bourdieu: Sociologia. São Paulo: Editora Ática, 1983. p. 122-155.

DELEUZE, Gilles. Foucault. São Paulo: Brasiliense, 1988.

FOUCAULT, Michel. O Sujeito e o Poder. Apêndice da 2a edição. Michel Foucault entrevistado por Hubert L. Dreyfus e Paul Rabinow. In.: DREYFUS, Hubert e RABINOW, Paul. Michel Foucault, uma trajetória filosófica: para além do estruturalismo e da hermenêutica. Rio de Janeiro: Editora Forense Universitária, 1995. 